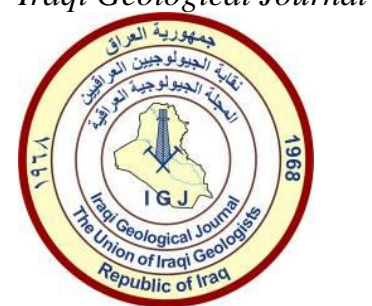

Iraqi Geological Journal

Journal homepage: https://www.igj-iraq.org

\title{
Characteristics of Carbonate Rocks and Environmental Conditions of Some Caves, Northern Iraq
}

\author{
Hiba A. Alobadi ${ }^{1}$, Azealdeen S. Al-Jawadi ${ }^{2, *}$ and Abdul Sattar A. Al-Sanjari ${ }^{1}$ \\ College of Environmental Science and Technology, University of Mosul, Mosul, Iraq \\ College of Petroleum and Mining Engineering, University of Mosul, Mosul, Iraq \\ * Correspondence: azealdeenaljawadi@uomosul.edu.iq
}

Received: 5 July 2021; Accepted: 29 August 2021; Published: 30 November 2021

\begin{abstract}
Six caves were studied in north Iraq, which is the Beeston and Shanidar in Erbil Garston, Swaratuka, and Ain Ishky in Duhok Governorate, Al-Naqut in Nineveh Governorate. All these caves are located within geological formations of carbonate rocks, limestone, and dolostone. Geotechnical and geometrical measurements were made for these caves, and rocks were sampled from different areas inside and outside the caves. The slake durability of the rocks was measured and thin sections were made, in addition to measuring the percentage of insoluble residues and analyzing the mineral constituents of the collected samples by using X-ray diffraction. By reviewing the geotechnical characteristics and environmental conditions, the Beeston Cave was found to be the oldest of the caves studied because its size is greater than that of the other caves and its rocks have better geotechnical characteristics than the other caves, which means that the time required for it to form is longer. The Al-Naqut Cave was also found to be the newest among these six caves because, in addition to its small size, it has the lowest durability value after the Shanidar Cave and has the lowest value of compressive strength.
\end{abstract}

Keywords: Carbonate rocks; Weathering; Geotechnical properties; Discontinuities; Caves; Iraq

\section{Introduction}

The carbonate rocks are one of the most soluble sedimentary rocks after salt rocks. The solubility in these rocks occurs because of the physical and chemical weathering processes resulting from the flow of solutions to and within these rocks (Awadh et al., 2013a; Awadh et al., 2013b). The effect of these solutions increases when carbon dioxide is dissolved in water to form carbonic acid, which works to dissolving and weathering carbonate rocks. The carbonate rocks are widespread across northern Iraq (Awadh and Nejbert, 2016). Besides, North Iraq can also include many primary karst areas, each with its characteristics (Abdula, 2021). The common karst types include underground river caves, blind valleys, natural bridges, pits, and sinkholes. The caves are not found in mountainous areas but also in most of Iraq, including the Western Desert (Al-Hetty et al., 2021) because they represent geological and environmental conditions. The structural units of the folds of northern Iraq represent steep slopes that accelerate the passage of surface water and groundwater. After the relatively acidic water from atmospheric precipitation seeps into the soluble carbonate rocks (Awadh et al., 2008), the water flows over the earth's surface and through the discontinuity surfaces along with the topographic trend. 
Environmental conditions of rock beds, geological structures, and hydrology lead to hidden karst caves, which can cause surface instability, karst collapse, water flow, mudflow, and other hazards (Sun et al., 2018). Physical weathering causes the fragmentation of rocks into smaller pieces, which leads to an increase in their total size, a decrease in bulk density, and an increase in the surface of the rocks. That is subject the rock to chemical weathering processes that in turn lead to a change in mineralization and therefore to its deterioration into less resistant mineral forms (Pope et al., 2015; Abdelhamid et al., 2020). Weathering is the physical and chemical change in the earth over time under the environmental influence of the atmosphere, water, and biology (Hack, 2020). The physical and chemical weathering of limestone could also dissolve and transfer from a solid to a liquid state (Heidari et al., 2017; Abdelhamid et al., 2020). Rainwater and temperature are among the most important external factors affecting the chemical weathering of rocks (Hack, 2020). Internal factors are represented by geotechnical characteristics, rock composition, and texture. Time is the third factor that the longer it takes, the more rocks deteriorate. External, internal, and time factors weaken the rock and reduce its strength (Dhakal, 1996; Pope et al., 2015). Karst forms and caves developed in Iraq as a result of the wide exposure spreads of carbonate and gypsum rocks, as well as the humid environmental conditions in the region during the Pleistocene and Holocene (Sissakian et al., 2015).

This study aims to establish the relations between the geological features and geotechnical characteristics of rocks with the environmental conditions leading to the formation and development of caves in northern Iraq. In the carbonate rocks of different geological formations, the Qamchuqa (Lower Cretaceous), Aqra-Bekhme (Upper Cretaceous), and Pila Spi (Middle-Upper Eocene), all the studied caves were formed. The Beeston and Shanidar caves are located in the Bradost Anticline in the Aqra-Bekhme and Qamchuqa formations, respectively. The Garston and Swaratuka caves are located in the Baikher Anticline within the Pila Spi Formation. The Ain Ishky cave is in the Mateen Anticline within the Qamchuqa Formation, and Al-Naqut cave is located in Maqloub Anticline within the Pila Spi Formation. Beeston Cave is located $70 \mathrm{~km}$ northeast of Erbil City, and Shanidar Cave is located $30 \mathrm{~km}$ northwest of Beeston Cave. Garston Cave is located within the city of Duhok on its northeastern tip, Swaratuka Cave tableis $30 \mathrm{~km}$ northeast of Duhok City, and Ain Ishky Cave is $20 \mathrm{~km}$ away from its predecessor. Al-Naqut Cave is located $30 \mathrm{~km}$ northeast of Mosul City (Fig. 1). Shanidar Cave is distinguished by the presence of the skeletal remains of Neanderthals (Solecki, 1957; Sissakian et al., 2016; Mohammad et al., 2017; Sissakian, 2021).

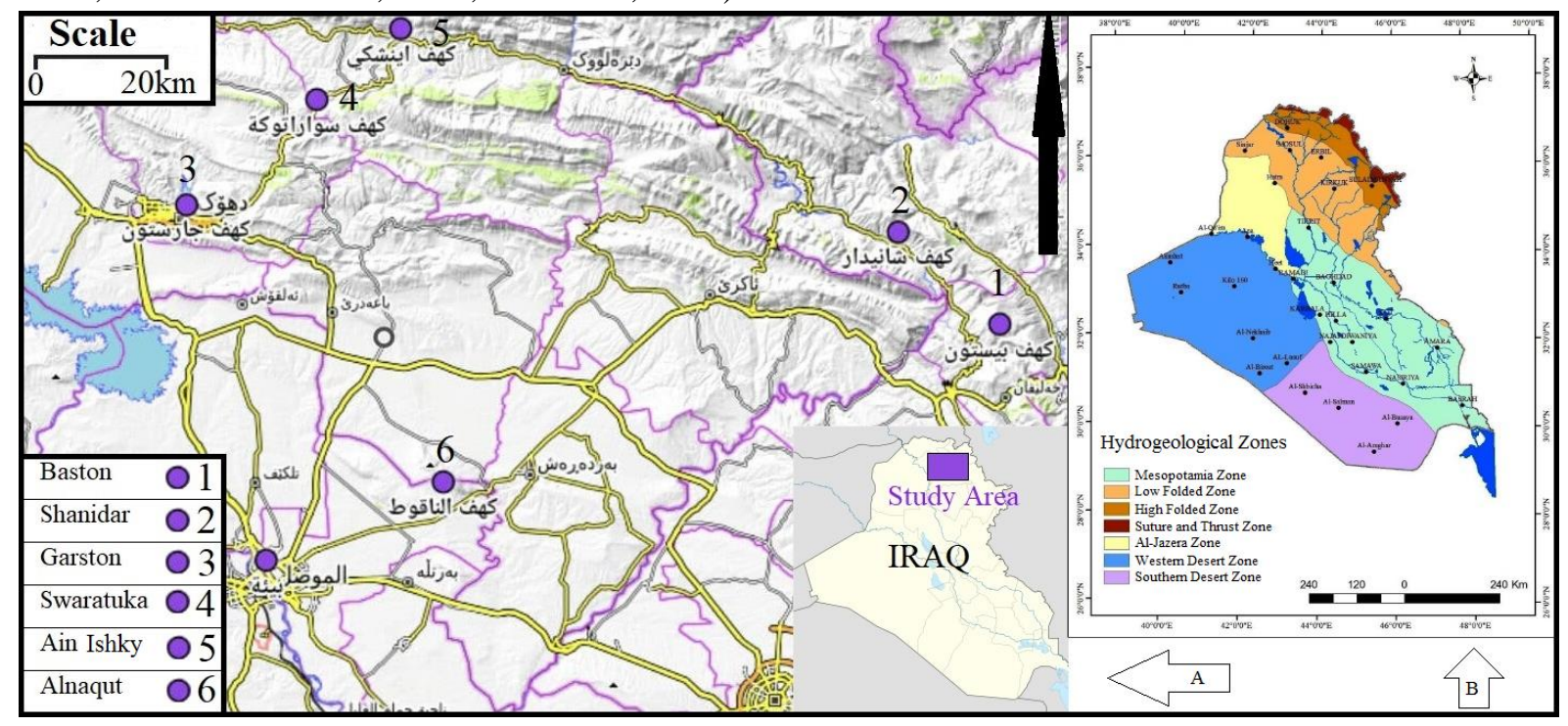

Fig. 1. (A) Location map showing the location of cave sites; (B) the hydrological zones of Iraq (Al-Jiburi and Al-Basrawi, 2015) 


\section{Materials and Methods}

Determination of the location of each cave concerning the geographical coordinates, geological structures, and formations was carried out. Cave openings and interior dimensions were measured. The geological compass was used to measure discontinuity attitudes, including bedding planes, joints, and fractures. Inside and outside of the caves, the Schmidt Hammer was used to measure the rebound number of the rocks to predict the compressive strength of rocks (Hudson and Harrison, 2000; Abdelhamid et al., 2020). The weathering degree of the rocks was identified on the walls, the floor, and the cave roof (ISRM, 1978). The rate of water discharge from the discontinuities and cavities was measured and sampled. The amount of water discharged was calculated by filling a known-size container with water that seeps or drips from the cave walls and roof over a while. Various representative samples of rocks were taken both inside and outside each cave from different locations. The laboratory work was carried out by cutting the rock and prepares thin sections to show the depth of weathering and taking samples with varying degrees of weathering to test the insoluble residue and the X-ray diffraction (XRD) (Fig. 2). Preparing thin sections for petrography studies to demonstrate how weathering influences rock texture and porosity. Four cycles of slake durability testing were conducted on samples representing the rocks of the studied caves to determine their ability or resistance to weathering. Therefore, in comparison with lithographic, petrographic, or structural variables, the relationship between the petrographic features of the carbonate rocks and the development of caves and karst features is a significant study (Devine, 2016).

During the desk work, the thin sections have been examined, sifted, photographed, and compared to other geotechnical characteristics. The thin section study is useful to assess the porosity, the relationship, and interrelationship between mineral grains as well as the formation of microscopic channels and the identification of minerals resulting from weathering processes (Devine, 2016). The relationships between the data obtained from the field measurements and laboratory experiments contributed to the environmental conditions that led to the formation of the caves and their current environment.

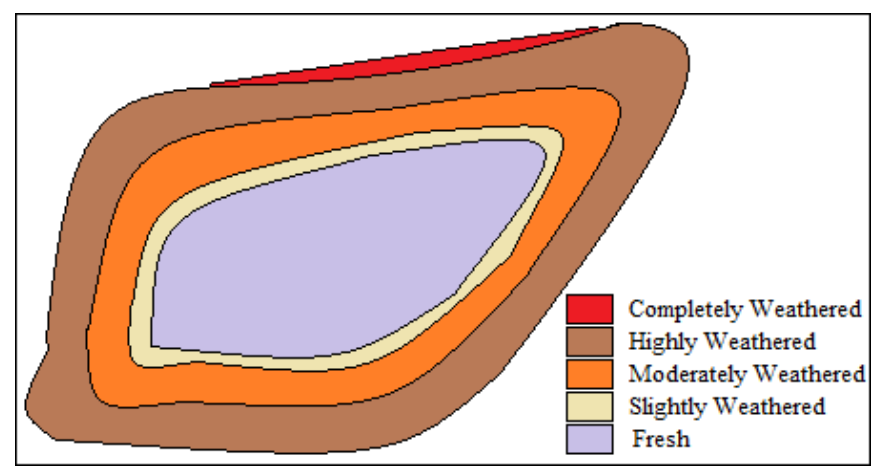

Fig. 2. Zonation of weathering grades in a hand spacemen from the surface (completely weathered) to the center (fresh)

\section{Results and Discussion}

The dimensions of the main cavity in the Beeston Cave are 40 meters long, 22 meters wide, and 8 meters high, making it one of the largest studied caves, as it extends a great distance of hundreds of meters, but in a smaller size. The extension of the cave channels reaches a distance of about 450 meters and extends towards the slope of the rock beds (Tevanovic, et al., 2009). The cave has three entrances close together and divided by two columns not exceeding two meters in height (Fig. 3 A and B). The cave is characterized by the abundance of huge stalagmites and stalactites some of which were connected to form pillars or even walls (Fig. $3 \mathrm{C}$ and D). On the roof of the cave, there is an upper opening with a diameter of 3 meters, and three side openings on the wall of the cave that represents the 
entrance (Fig. $3 \mathrm{E}$ and F). The cave is located close to the axis of the Bradost Anticline in the hinge zone, and therefore the inclination of the beds is observed to the southwest.

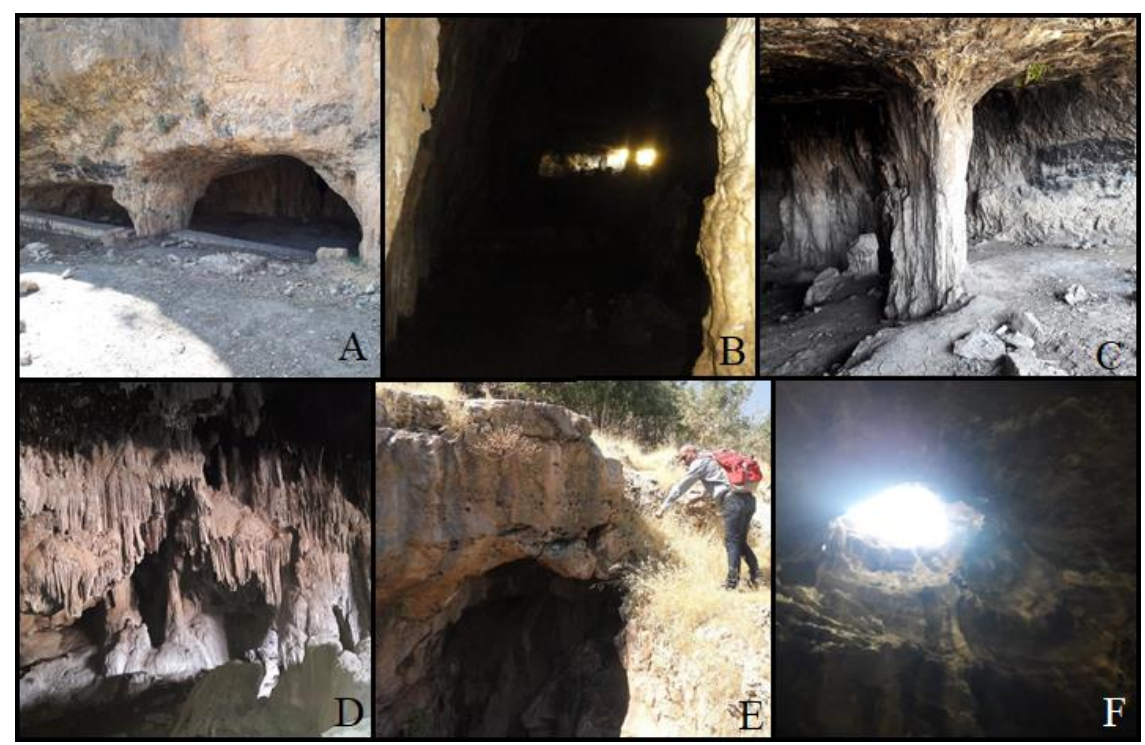

Fig. 3. The Beeston Cave (A) Outside view of the entrance of the cave; (B) Inside view of the entrance of the cave; (C and D) The connection between stalactite and stalagmite is horizontally and vertically to form pillars and walls; (E) The roof opening from the surface; (F) Inside view of the roof opening

The Shanidar Cave has a triangular entrance with a height of about $12 \mathrm{~m}$ and that it is smaller than the Beeston Cave as its area reaches $400 \mathrm{~m}^{2}$ (Tevanovic et al., 2009), and there are excavation processes in this cave indicating that the Neanderthals lived in it (Fig. 4 A and B). The cave is located in the southwestern limb of Bradost Anticline Gali Shakfte, in front of the Greater Zab River (Fig. 4 and Table 1), at a height (768) m (a.s.l.). Sissakian (2021) studied this cave thoroughly as it is one of the important geological and historical landmarks and suggested considering it as a National Park in northern Iraq. It is believed that the size of the cave is small as compared to the Beeston Cave because the rocky environment of the cave is composed of massive rock mass (Tevanovic et al., 2009) having a relatively large spacing of discontinuities (Fig. $4 \mathrm{C}$ and D).

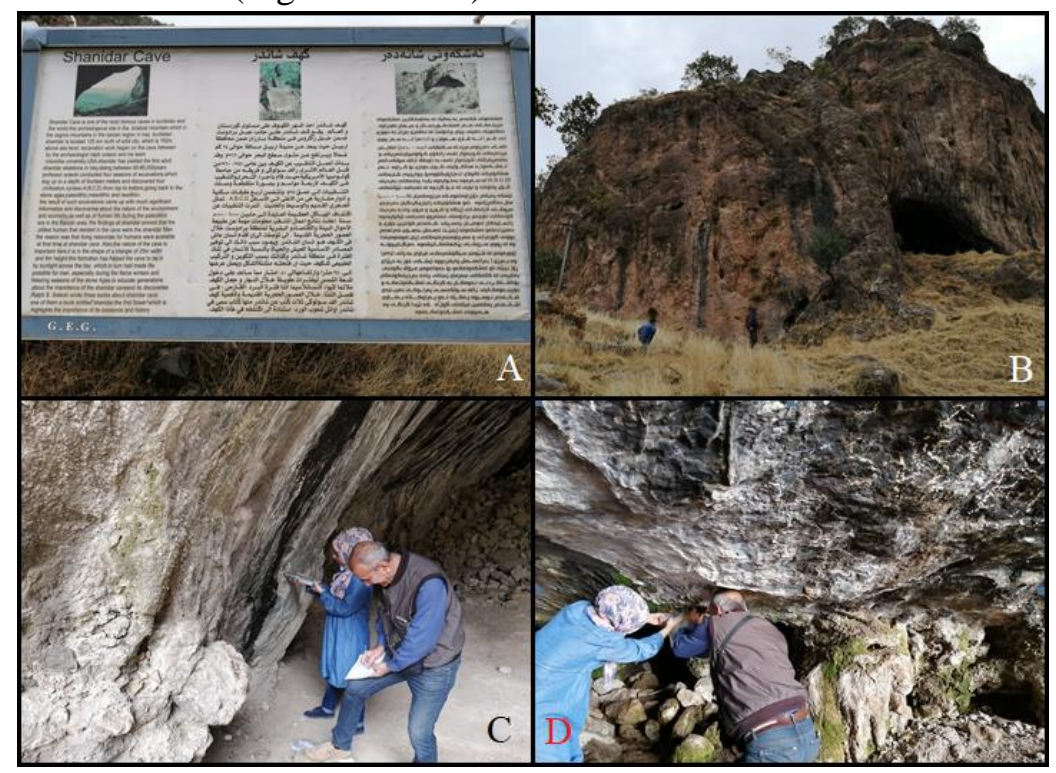

Fig. 4. The Shanidar Cave; (A) An identification board for tourist purposes; (B) Cave view from outside ;(C) Measurement of the rebound number by Schmidt hammer on the massive rock mass; (D) Sampling and measuring the amount of leaching of the cave water from the wide spacing discontinuities 
Table 1. Geographical position data for caves locations

\begin{tabular}{cccc}
\hline Cave & Latitude & Longitude & Elevation m (a.s.l.) \\
\hline Beeston & $36^{\circ} 42^{\prime} 28.45^{\prime \prime} \mathrm{N}$ & $44^{\circ} 23^{\prime} 34.11^{\prime \prime} \mathrm{E}$ & 1489 \\
Shanidar & $36^{\circ} 50^{\prime} 04.70^{\prime \prime} \mathrm{N}$ & $44^{\circ} 13^{\prime} 09.42^{\prime \prime} \mathrm{E}$ & 768 \\
Garston & $36^{\circ} 51^{\prime} 47.58^{\prime \prime} \mathrm{N}$ & $42^{\circ} 59^{\prime} 18.53^{\prime \prime} \mathrm{E}$ & 624 \\
Swaratuka & $37^{\circ} 00^{\prime} 56.98^{\prime \prime} \mathrm{N}$ & $43^{\circ} 13^{\prime} 31.31^{\prime \prime} \mathrm{E}$ & 1157 \\
Ain Ishky & $37^{\circ} 06^{\prime} 46.41^{\prime \prime} \mathrm{N}$ & $43^{\circ} 22^{\prime} 08.00^{\prime \prime} \mathrm{E}$ & 1258 \\
Al-Naqut & $36^{\circ} 29^{\prime} 31.95^{\prime \prime} \mathrm{N}$ & $43^{\circ} 26^{\prime} 29.72^{\prime \prime} \mathrm{E}$ & 798 \\
\hline
\end{tabular}

A karst cavity was carved to form the Garston Cave by humans, as this cave was developed by ancient humans and was considered a place of religious rituals at the time according to the personal communication with the General Directorate of Tourism, Duhok. There are four pillars in this cave that were kept after removing the rest of the rocks, and the name of the cave in Kurdish means the four pillars (Fig. 5 A). These pillars are based on a square base with dimensions of 4 meters on which the religious rituals were held. The entrance to the cave is relatively long, up to 9 meters and two meters in height. This cave is located in the southwestern limb of Baikher Anticline near the Duhok Dam and is considered a tourist and archaeological landmark in the area (Fig. 1 and Table 1). The presence of green-colored decomposed mineral on the discontinuity caused by moisture, indicating a reducing environment (Fig. 5 B).

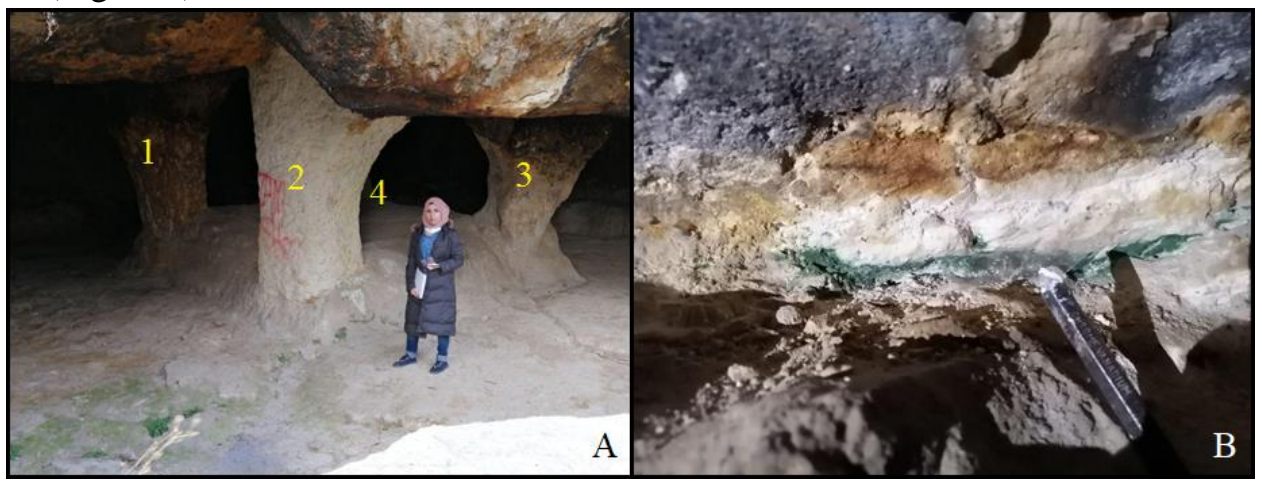

Fig. 5. The Garston Cave; (A) The four pillars in the center of the cave; (B) The alteration of parent rocks and decomposition of minerals

The Swaratuka cave appeared because of the road expansion is characterized by its small size compared to other caves (Fig. 6 A). The maximum length of the cave is 12 meters, its width is 7 meters, and its height is not more than 3 meters. This cave is formed because of water flowing through the discontinuity surfaces that formed a karstic cavity within the rocks (Fig. $6 \mathrm{~B}$ and C).

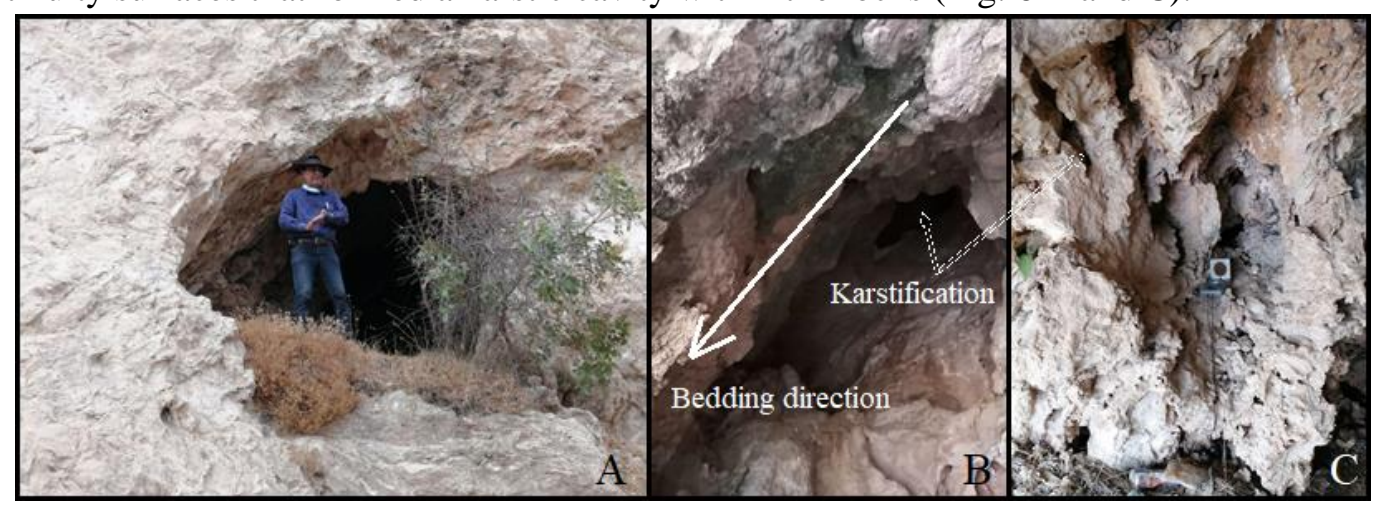

Fig. 6. The Swaratuka Cave; (A) The small entrance of the cave; (B) Bedding direction; (B and C) karstification along discontinuities 
The Ain Ishky Cave is one of the oldest tourist attractions in northern Iraq, and it is characterized by its capacity and a little height from the surrounding areas (Sissakian, 2021). The shape of the cave is semi-oval and has meanders on the inside. The average length of the large and small diameters is 30 meters and 25 meters, respectively. This cave is characterized by the plant and micro-organisms activities in it, as the roots of plants extend inside the cave, as well as the presence of pores and soft sediments covering most of the cave walls as a result of the activity of micro-organisms (Fig. 7). The cave is located in the southwestern limb of Mateen Anticline.

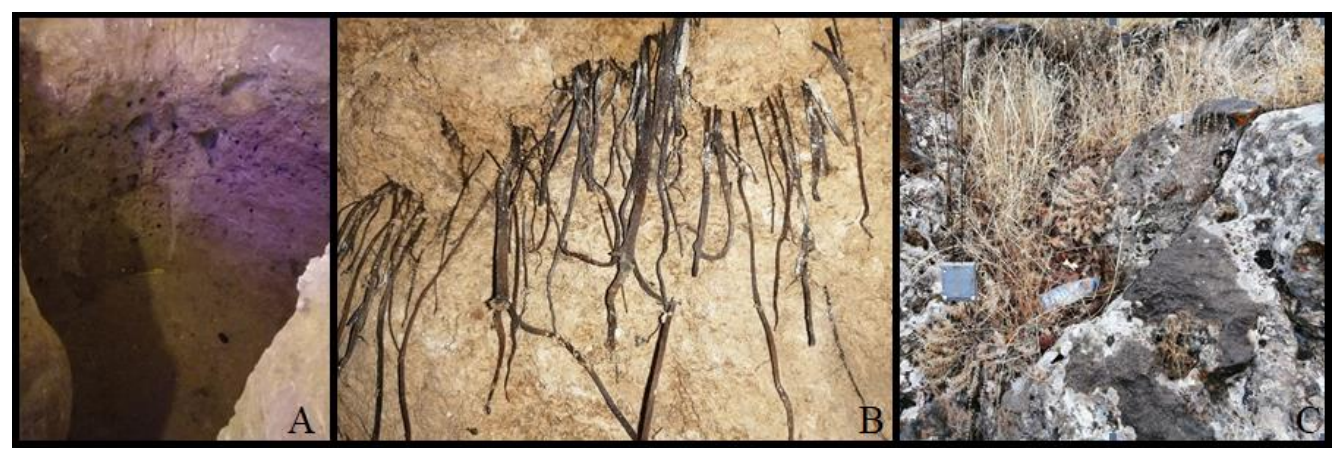

Fig. 7. The Ain Ishky Cave; (A) Dense Pores in the rocks inside the cave; (B) Growth of plants root inside the cave; (C) Highly porous rocks outside the cave

Al-Naqut Cave is in the Maqloub Mountain in the vicinity of the Mar Matti Monastery and is named after water dripping from the roof during the entire year (Fig. $8 \mathrm{~A}$ and B). This cave is the small remaining part of a large cave that was destroyed due to the accumulated influence of weathering processes, the geological situation, and the surrounding environmental conditions (Fig. 8 B). The block size classification in the study area is sometimes small or medium and the surfaces of discontinuities are characterized by wet to damp (Al-Jawadi, 2021), which helps develop cavities in the area (Fig. 8 C).

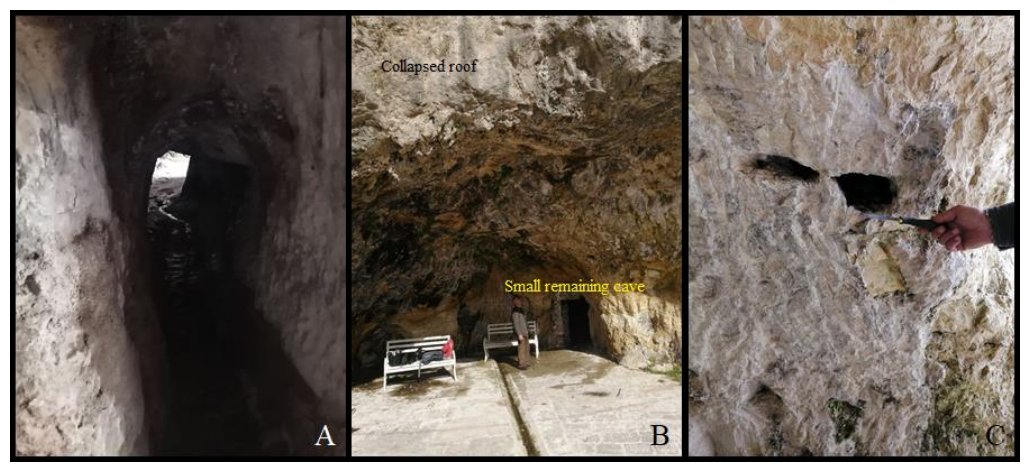

Fig. 8. Al-Naqut Cave; (A) The entrance of the cave showing the water flow; (B) Remnant roof of the major cave and the entrance of the recent cave; (C) Development of cavities along discontinuities

Stereographic projections demonstrated the relationship between the size and extension of the studied cave with their discontinuities attitude and geotechnical characteristics (Fig. 9). The highest dip of the rock beds was in the Ain Ishky, Garston, and Swaratuka caves, respectively, as their dip was more than 30 degrees, and the lowest dip was in the Beeston, Shanidar, and Al-Naqut caves, respectively, and their dip was less than 20 degrees (Fig. 9). The highest average of the different types of discontinuity spacing was in the Shanidar Cave and the lowest in the Swaratuka Cave. Most of these six caves extend towards the bedding surface and intersect it with one or both of the joint sets, Set 1 or Set 2 since the roof and floor of the cave represent the bedding surface. It was found that the Beeston, Shanidar, and Ain Ishky caves extend to the southwest, Garston, and Al-Naqut caves to the south, and the Swaratuka Cave to the northwest (Fig. 9). These directions correspond with the direction of the groundwater movement 
that is generally south to the southwest (Al-Jiburi and Al-Basrawi, 2015). The surface water passes into the rocks through a top opening, Beeston, Ain Ishky, and Al-Naqut were created, whereas other caves developed by the passing of the groundwater through the surfaces of the discontinuities (Fig. 10).
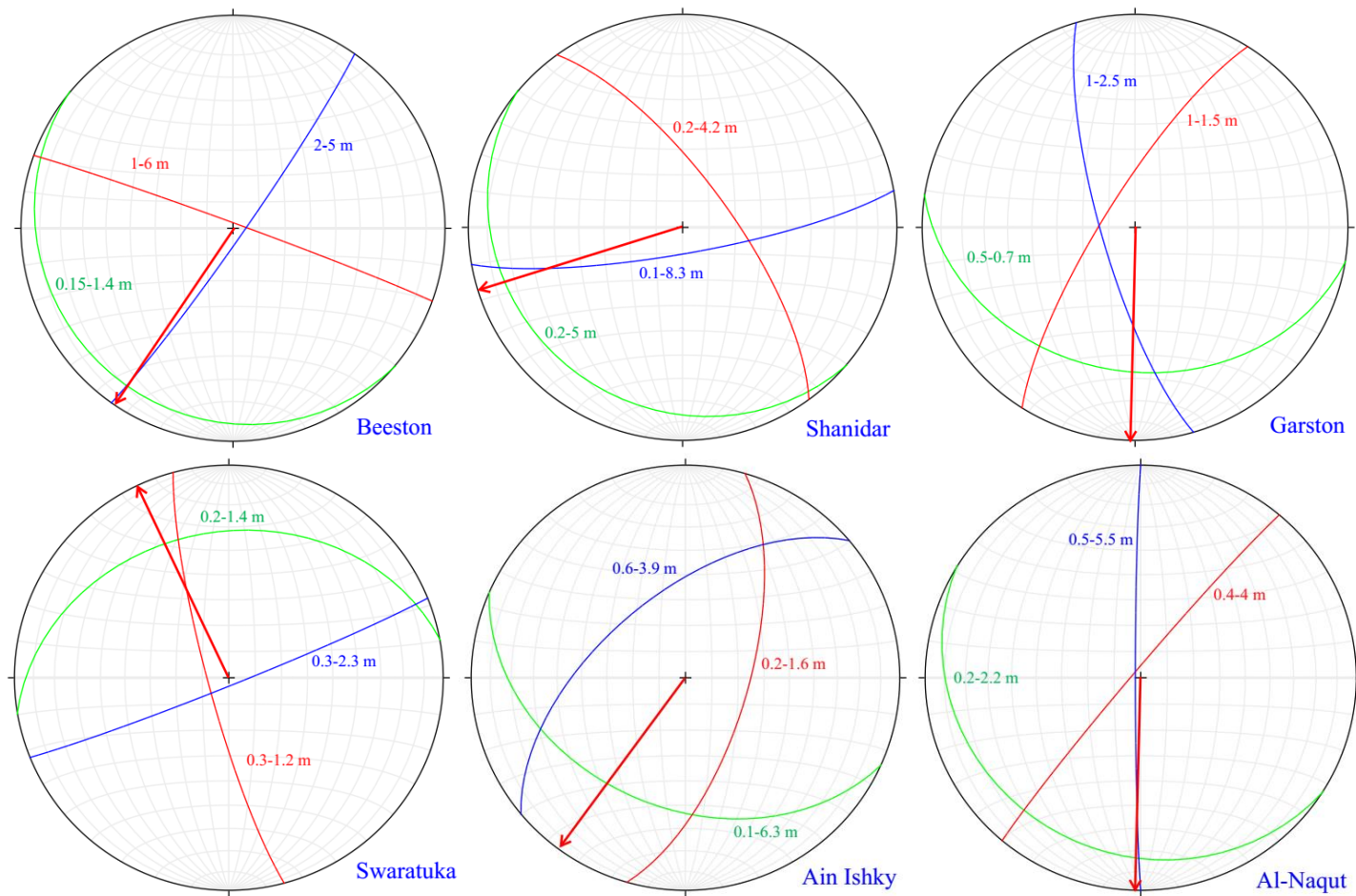

Bedding plane

Set 1

Set 2

Cave direction

0.4-4 $\mathrm{m}$ Spacing

Fig. 9. The stereo net lower hemisphere projection of the bedding planes for each cave and the approximate extension of each cave

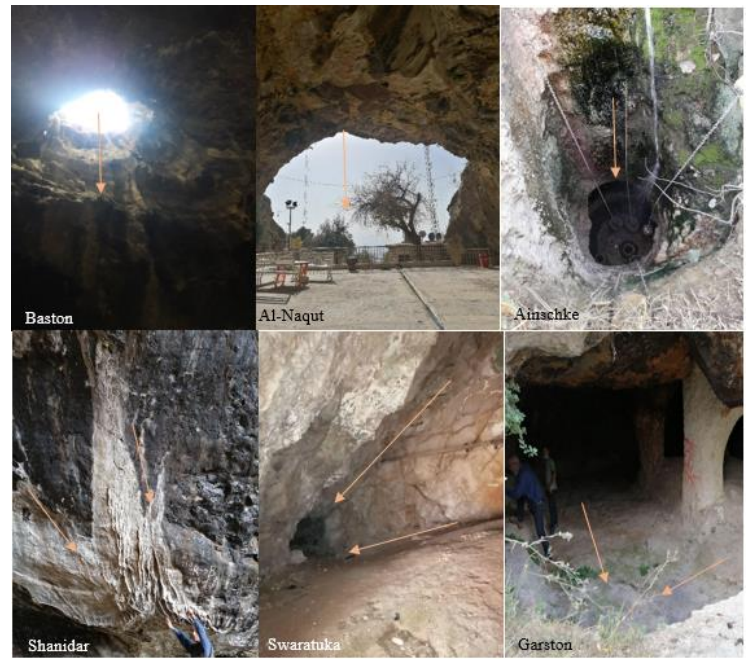

Fig. 10. Photos of caves showing the water direction

Rocks are heterogeneous, a moderate relationship between their engineering properties is therefore good. The correlation coefficient between the uniaxial compressive strength UCS (Table 2) and the fourth slaking cycle (Table 3) was close to 0.5 (Fig. 11), so this relationship is considered good and gives an impression on the possibility for caves to be formed, their sizes, and their age (Moeyersons, et al., 2002; Germinario et al., 2020). All geotechnical characteristics affect the possibility of cave 
formation depending on the environment of the area and the geological and hydrological conditions. Fig. 11 shows that the Beeston Cave has good field and laboratory characteristics, while its size is greater than other caves, hence it be considered the oldest one. The Shanidar Cave has good field geotechnical properties, and fair laboratory properties, as well as it is smaller than the Beeston Cave, thus it is considered newer. The Ain Ishky and Swaratuka caves are of similar age, while the Al-Naqut Cave is newer than all of them. The Garston Cave is an exception because ancient humans expanded it. As the environmental conditions are harsh on the rocks, the degree of weathering increases, the carbonate rocks decompose, clay minerals are formed, and the percentage of insoluble components in them increases until they reach the degree of complete weathering, so the percentage of insoluble materials in them decreases (Fig. 12) due to the washing process (Al-Jawadi and Al-Dabbagh, 2020).

Table 2. The average physical and mechanical properties of rocks forming the studied caves.

\begin{tabular}{llllllll}
\hline Cave & $\begin{array}{l}\text { Dry Density } \\
\text { gm/cc }\end{array}$ & $\begin{array}{l}\text { Wet Density } \\
\text { gm/cc }\end{array}$ & $\begin{array}{l}\text { Porosity } \\
\text { \% }\end{array}$ & $\begin{array}{l}\text { Voids } \\
\text { ratio } \%\end{array}$ & $\begin{array}{l}\text { UCS }_{\mathbf{i}} \\
\mathbf{M P a}\end{array}$ & $\begin{array}{l}\text { Sig. c. } \text { m }^{* * *} \\
\mathbf{M P a}\end{array}$ & $\begin{array}{l}\mathbf{U C S}_{\mathbf{m}} \\
\mathbf{M P a}\end{array}$ \\
\hline Beeston & 2.4297 & 2.4855 & 5.58 & 6.08 & 14.78 & 2.67 & 1.18 \\
Shanidar & 2.2662 & 2.311 & 4.48 & 4.69 & 7.14 & 1.34 & 0.79 \\
Garston & & & & 6.89 & 1.17 & 0.54 \\
Swaratuka & 2.4035 & 2.4508 & 4.74 & 4.98 & 7.01 & 1.82 & 1.32 \\
Ain Ishky & 1.9559 & 2.1325 & 17.66 & 21.45 & 9.12 & 0.81 & 0.16 \\
Al-Naqut & 1.9195 & 2.1269 & 20.74 & 26.22 & 5.51 & 0.96 & 0.46 \\
${ }^{*}$ Estimated value by Schmidt Hammer test, ${ }^{* *}$ Global rock mass strength, intact rock, m rock mass \\
\hline
\end{tabular}

Table 3. The average slakes durability test for four cycles

\begin{tabular}{lclllllll}
\hline Cycle & Cave & Beeston O & Beeston I & Shanidar & Garston & Swaratuka & Ain Ishky & Al-Naqut \\
\hline \multirow{2}{*}{1} & Slake & 99.58 & 98.3 & 96.7 & 98.68 & 96.6 & 97.3 & 97.17 \\
& Durability & 0.42 & 1.7 & 3.3 & 1.32 & 3.4 & 2.7 & 2.83 \\
2 & Slake & 99.13 & 97.91 & 94.62 & 98.34 & 96 & 96.13 & 95.14 \\
& Durability & 0.87 & 2.9 & 5.38 & 1.66 & 4 & 3.87 & 4.86 \\
3 & Slake & 98.72 & 97.79 & 92.19 & 97.76 & 95.26 & 95.2 & 94.79 \\
& Durability & 1.28 & 2.21 & 7.81 & 2.24 & 4.74 & 4.8 & 5.21 \\
4 & Slake & 98.58 & 97.35 & 91.31 & 97.38 & 94.8 & 94.66 & 92.52 \\
& Durability & 1.42 & 2.65 & 8.69 & 2.62 & 5.2 & 5.34 & 7.48 \\
& & & O: outside the cave; I: inside the cave \\
\hline
\end{tabular}

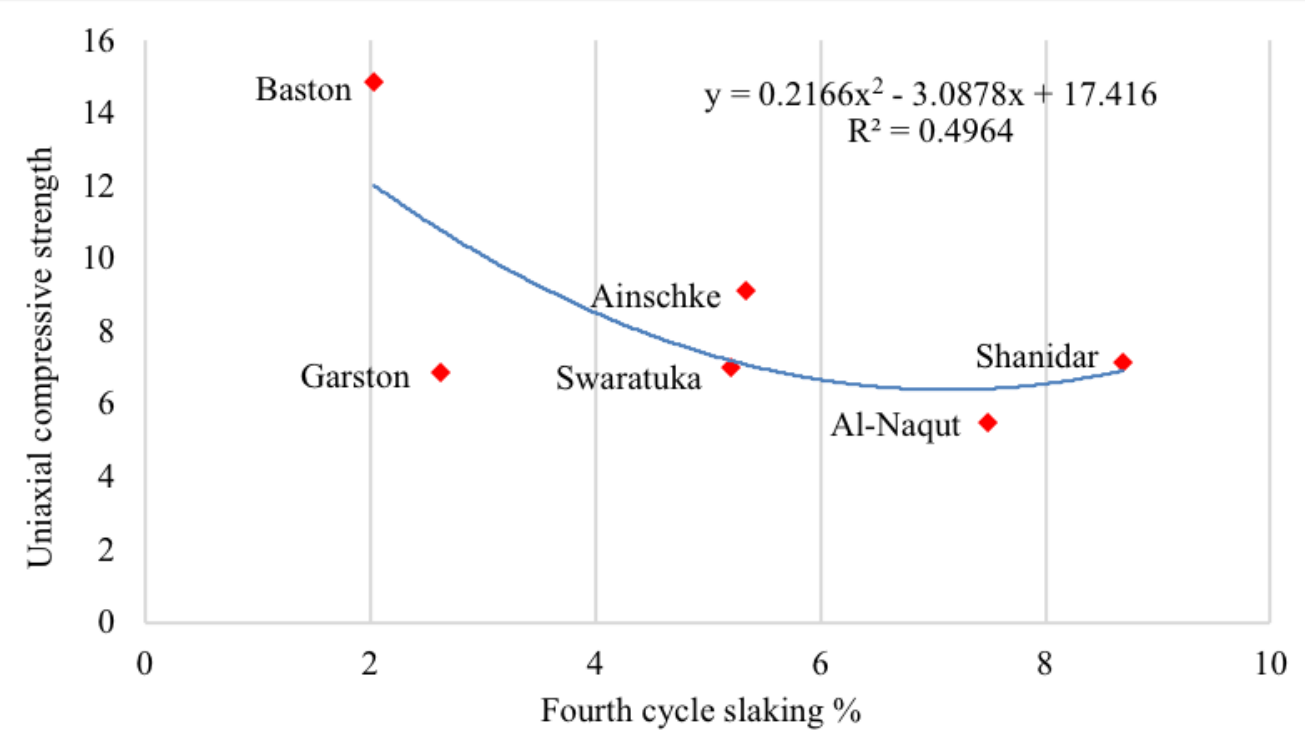

Fig. 11. The relationship between uniaxial compressive strength and the fourth cycle of slaking 


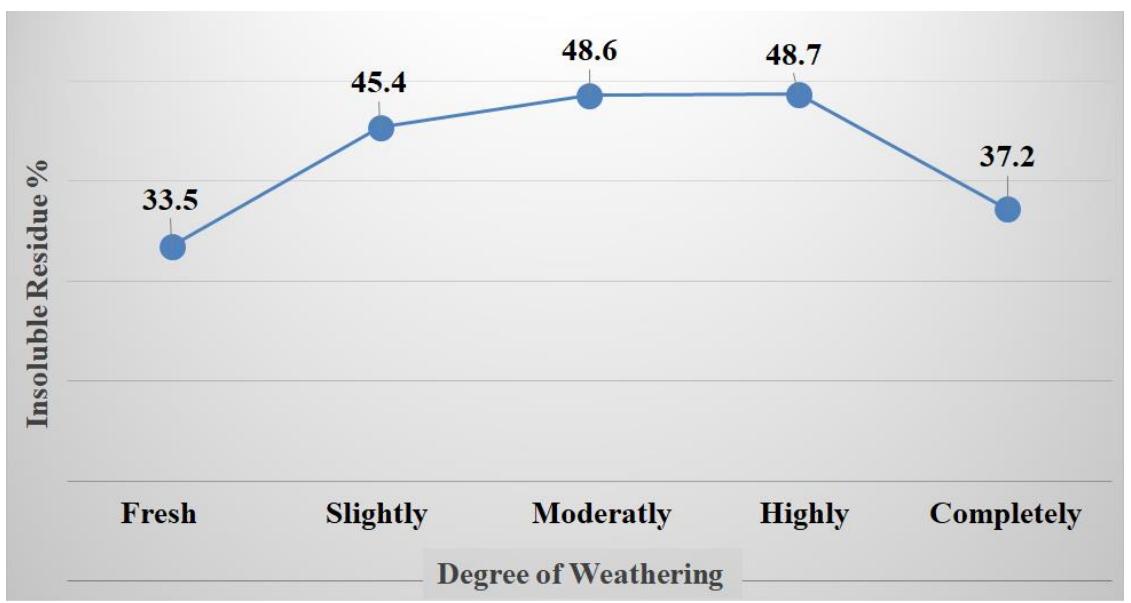

Fig. 12. The relationship between the degree of weathering and the insoluble residue

The porosity test verified that there was a rise in porosity in each of the weathered rocks of the Ain Ishky and Al- Naqut caves and that it was in the form of channels or connected pores (Fig. 13 and Table 2). In comparison to the previous two caves, the remaining caves had a porosity of medium-to-low. The mineralogical study, by analyzing the samples with different degrees of weathering by XRD analysis, showed that the rocks surrounding the Beeston Cave were calcite and a little dolomite, while the Garston, Al-Naqut, and Swaratuka caves were dolomite and a little calcite. This study showed that fresh rocks lack the presence of clay minerals and quartz, while these minerals appear in weathered rocks at low, medium, and high degrees, and then decrease in completely weathered rocks (Fig. 14).

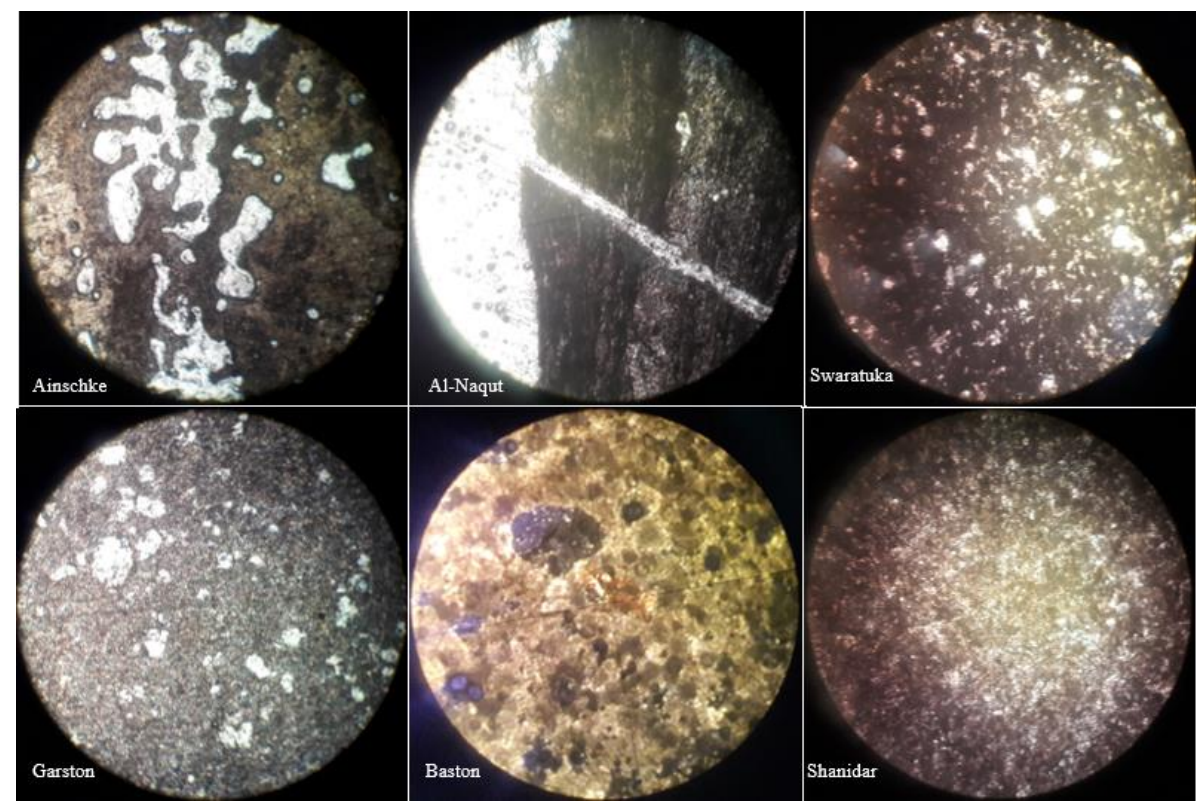

Fig. 13. Microscopic photos show the different porosities of caves rocks, top (high porosity), moderate (moderate porosity), and bottom (low porosity), diameter $3 \mathrm{~mm}$

The internal environment of the Beeston, Shanidar, and Al-Naqut Caves are wet, as water drips from the roof and runs on the walls, while the rest of the caves were dry. By analyzing the water of the first three caves, it was found that the water that drips from the roof of the Beeston Cave is somewhat acidic, as its average $\mathrm{pH}$ value is 6.7, and for the water, on the floor of the cave is basic, it is 8.6. In the Shanidar and Al-Naqut caves, the water is basic and its average was 8.7, which may be due to the remains of animals (dung). From this, it can be concluded that the quality of the water in the roof of the 
Beeston Cave is somewhat acidic, indicating the large size of the cave and that its basic nature in the Shanidar and Al-Naqut caves indicates their relatively small size. Previous studies showed that groundwater in the Low Folded Zone and High Folded Zone is freshwater with salinity less than 500 $\mathrm{mg} / \mathrm{l}$, while karst water is prevailing bicarbonate (Al-Jiburi, and Al-Basrawi, 2015).

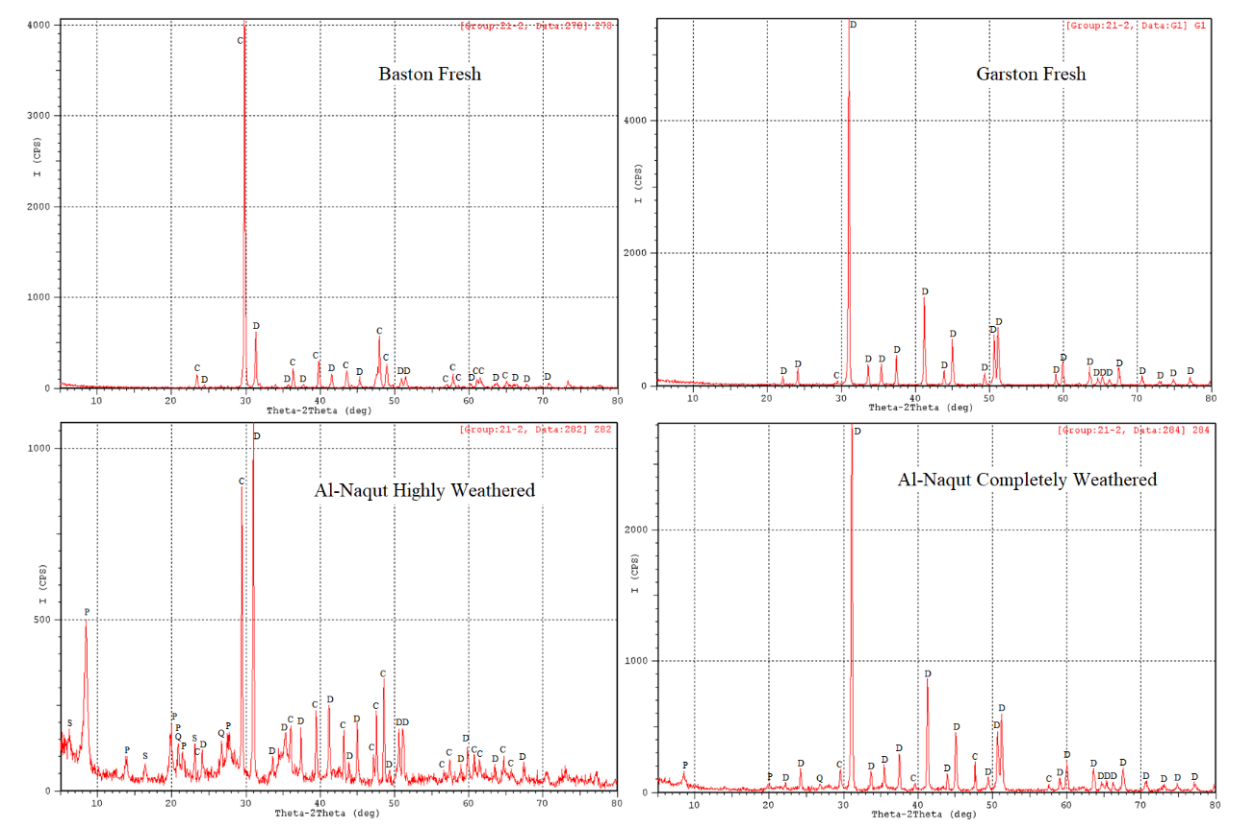

Fig. 14. XRD analysis of some cave rocks showing the appearance and disappearance of clay minerals and quartz in different degrees of weathering

By preparing a scenario for the formation of these caves, all the results of the study can be summarized, determine their size, shape, extension, and relative age. Through the stereographic projection, it was found that the extension of the caves is in line with the slope of the bedding plane in general or on the trend of their intersection with one of the other discontinuities Set 1 and Set 2 that represent the zones of weakness through which the water passes. The passage of surface water through the surfaces of the discontinuities led to the dissolution of the weak rock beds in the Beeston, Ain Ishky, and Al-Naqut caves (Fig. 15). The evidence for this is the occurrence of water entering through roofs of these caves (Fig. 10) and its flow towards the surfaces of the stratification or the intersection trend.

Al-Naqut Cave differs from the rest because most of its roofs have collapsed (Figs. 8, 10, and 15), leaving only the trace of the opening in the facade of the cave. The trace of this collapse is present by the pieces of roof rock fragments scattered in front of the cave and away from the current remaining part. There is another reason that led to the fall of most of the roof of the cave, which is the presence of the trace of a dissolution channel with a diameter of more than 1.5 meters along the eastern side and its level at the lowest level of the collapsed roof. The passage of groundwater through the discontinuity surfaces led to the creation of the Shanidar Cave, and the openness of these surfaces increased to varying degrees, with the largest opening leading to the development of the cave. The triangular shape of the cave opening and the pyramidal shape of the cave were the results of dissolving rocks through the discontinuity surfaces, and their intersections (Hack, 2020). The Swaratuka Cave was developed in the same manner as the Shanidar Cave, although it persisted in the form of an invisible karst opening until it was severed by road expansion operations connecting Duhok City and Amadiyah District, and its general direction is towards Set 2 and its intersection with the bedding. Finally, the Garston Cave is considered to have been a small cave that was enlarged and was used as a temple by ancient humans, yet the direction of the cave is in line with the direction of the bedding inclination and intersecting with the 
other two surfaces of the discontinuity. The large size of the Beeston Cave is due to the longevity of the cave, which is expected to extend from the age of the Pleistocene and the favorable climatic conditions to which it was formed (Sissakian et al., 2015). The Shanidar Cave is also relatively old compared to the rest of the caves because it was formed in mass rocks, and the surface of the rocks exposed to water is less in such a case. The Shanidar Cave is more than 100,000 years old (Solecki, 1957), so the Beeston Cave may be formed before that. The Ain Ishky Cave has a special character in its formation because plants and microorganisms helped in this, and it is noticed that they spread throughout the cave.
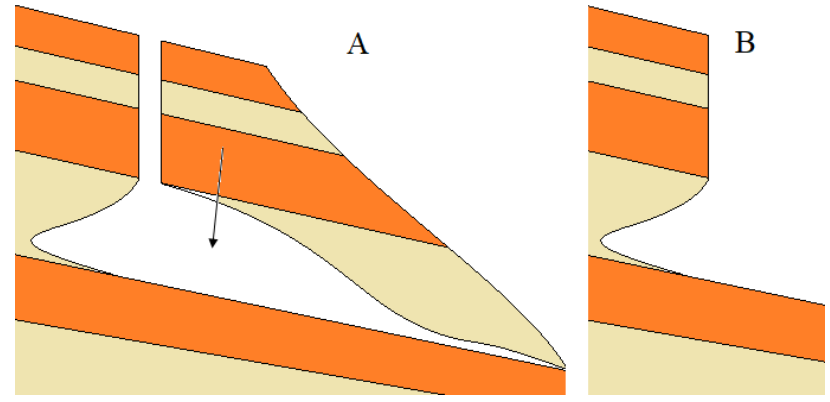

Fig. 15. The scenario of Al-Naqut Cave formation

\section{Conclusions}

The conclusion arises from this study, the possibility of comparison in evaluating the relative ages of caves by studying the environmental, geotechnical, and hydrogeological characteristics. It was found that the impact of the petrography, groundwater, and time has the greatest influence on the formation of caves. These conditions weaken the geotechnical properties of the rock masses and thus greatly increase the size and expansion of the cave. It was also found that the effect of surface water seeping through the surfaces of the discontinuities has a significant impact on the formation of caves in carbonate rocks. The direction of expansion of the cave is consistent with the movement of groundwater through the discontinuities surfaces and is elongated in that direction. The directions of the discontinuities surface of all kinds and their geotechnical characteristics affect the shape and size of the cave and this is evident in the Shanidar Cave, as it took a pyramidal shape in line with the directions of the discontinuity's surfaces, as well as the Swaratuka Cave. The study of caves and the conditions that make up them can be used in engineering projects that are built on or in carbonate rocks and avoid problems that may occur. The environment of caves is one of the distinctive environments in many investment businesses, as it can be used in the tourism, medical and agricultural fields related to mushroom growth, in addition to that it represents a moderate temperature environment throughout the year.

\section{Acknowledgements}

The authors would like to express gratitude to the University of Mosul, Mosul, Iraq for their support to complete this work. The authors are very grateful to the Deans of College of Environmental Science and Technology, and the College of Petroleum and Mining Engineering, and their staff. The authors are very grateful to the Editor in Chief Prof. Dr. Salih M. Awadh, the Secretary of Journal Mr. Samir R. Hijab. and the Technical Editors for their great efforts and valuable comments.

\section{References}

Abdelhamid, M.M.A., Li, D. and Ren, G., 2020. Predicting unconfined compressive strength decrease of carbonate building materials against frost attack using nondestructive physical tests, sustainability, Multidisciplinary Digital Publishing Institute, 12(4), 1379.

Abdula, R.A., 2021. Speleology of Kospi Spi Cave in northern Iraq', The Iraqi Geological Journal, $126-133$. 
Al-Hetty, S.O., Al-Jibouri, A.S. and Abed, A.M., 2021. Description of the karst phenomena spreading along stratified sequence in the western desert of Iraq, Iraqi Geological Journal, 54(1B), 94-101.

Al-Jawadi, A. S., 2021. Theoretical models of slope stability analysis in the Maqlub Mountain rock cut routes, north Iraq, Iraqi Geological Journal, 54(1B), 55-68.

Al-Jawadi A. S. and Al-Dabbagh, T.H., 2020. The effects of weathering on limestone used for building the cemetery wall in Tel Kaif-North Iraq', Iraqi national Journal of Earth Science, 20(1), 56-74.

Al-Jiburi, H.K., A. and Al-Basrawi, N.H., 2015. Hydrogeological map of Iraq, scale 1:1000 000, 2013', Iraqi Bulletin of Geology and Mining, 17-26.

Awadh, S.M., Abood, Z.S. and Eisa, M.J., 2013a. Chemical and physical control processes on the development of caves in the Injana Formation, Central Iraq. Arabian Journal of Geosciences, 6(10), 3765-3772.

Awadh, S.M., Ali, K.K. and Alazzawi, A.T., 2013b. Geochemical exploration using surveys of spring water, hydrocarbon and gas seepage, and geobotany for determining the surface extension of Abu-Jir Fault Zone in Iraq: A new way for determining geometrical shapes of computational simulation models. Journal of Geochemical Exploration, 124, 218-229.

Awadh, S.M. and Nejbert, K., 2016. Polymetallic sulfide ores hosted in Late Permian carbonate at the Alanish locality, northern Iraq: petrography and mineral chemistry. Arabian Journal of Geosciences, 9(9), 1-15.

Awadh, S.M., Habib, H.R. and Al-Bassam, K.S., 2008. Upper Cretaceous carbonate hosted zinc-lead-barite deposits in Northern Thrust Zone, northern Iraq: petrography and geochemistry. Arabian Journal of Geosciences, 1(1), 75-85.

Devine, S. M., 2016. Petrographic controls on weathering of the Haney Limestone, Western Kentucky University.

Dhakal, G.P., 1996. Potentials of Granite and Diorite as Construction Aggregates', MSc. Thesis, Asian Institute of Technology, Bangkok, Thailand, 92 pp.

Germinario, L., Oguchi, C.T., Tamura, Y., Ahn, S., and Ogawa, M., 2020. Taya Caves, a Buddhist marvel hidden in underground Japan: stone properties, deterioration, and environmental setting, Heritage Science, 8(1), $1-20$.

Hack, H.R.G.K., 2020. Weathering erosion and susceptibility to weathering, Soft Rock Mechanics and Engineering, 9(11), 291-333.

Heidari, P., Li, L., Jin, L., Williams, J.Z., and Brantley, S.L., 2017. A reactive transport model for Marcellus shale weathering, Geochimica et Cosmochimica Acta, 217, 421-440.

Hudson, J. A. and Harrison, J.P., 2000. Engineering Rock Mechanics: An Introduction to the Principles, Elsevier, 458 pp.

ISRM, 1978. Suggested methods for the quantitative description of discontinuities in rock masses, International Journal Rock Mechanism. 15, 319-368.

Moeyersons, J., Vermeersch, P.M. and Van Peer, P., 2002. Dry cave deposits and their palaeoenvironmental significance during the last $115 \mathrm{ka}$, Sodmein Cave, Red Sea Mountains, Egypt, Quaternary Science Reviews, 21(7), 837-851.

Mohammad, M. K., Afrasiab, S. R., Al-Zubaidi, A. A., and Abdul-Rassoul, M. S., 2017. Survey for cave animals of Iraqi Kurdistan, Journal of Biodiversity and Environmental Sciences, 10(5), 217-232.

Pope, G.A., Aryamontri, D.C., Wu, L., and Renner, T., 2015. Deterioration of stone and mineral materials from the Roman Imperial "Villa of the Antonines" at Ancient Lanuvium, in Engineering Geology for Society and Territory, Springer, 8, 495-501.

Sissakian, V. K., Abdul Ahad, A. D., Al-Ansari, N. and Knutsson, S., 2016. Tourism in north and northeastern parts of Iraq, Journal of Earth Sciences and Geotechnical Engineering, 1792-9660.

Sissakian, V.K., Al-Ansari, N. and Knutsson, S., 2015. Karst forms in Iraq, Journal of Earth Sciences and Geotechnical Engineering, 5(4), Scienpress Ltd, 1-25.

Sissakian, V.K., 2021. Shanidar Cave in northern Iraq (Kurdistan Region), a national geopark recommendation, Iraqi Geological Journal, 54(1C), 137-145.

Solecki, R.S., 1957. 'Shanidar Cave', Scientific American, 197(5), pp. 58-65.

Sun, S., Ki, L., Wang, J., Shi, S., Song, S., Fang, Z., Ba, X. and Jin, H., 2018. Karst development mechanism and characteristics based on comprehensive exploration along Jinan Metro, China, sustainability, 10, 1-21.

Tevanovic, Z., Iurkiewicz, A. and Maran, A., 2009. New insights into karst and caves of northwestern Zagros (Northern Iraq), ACTA Carsologica, Postojna, 38(1), 83-9 